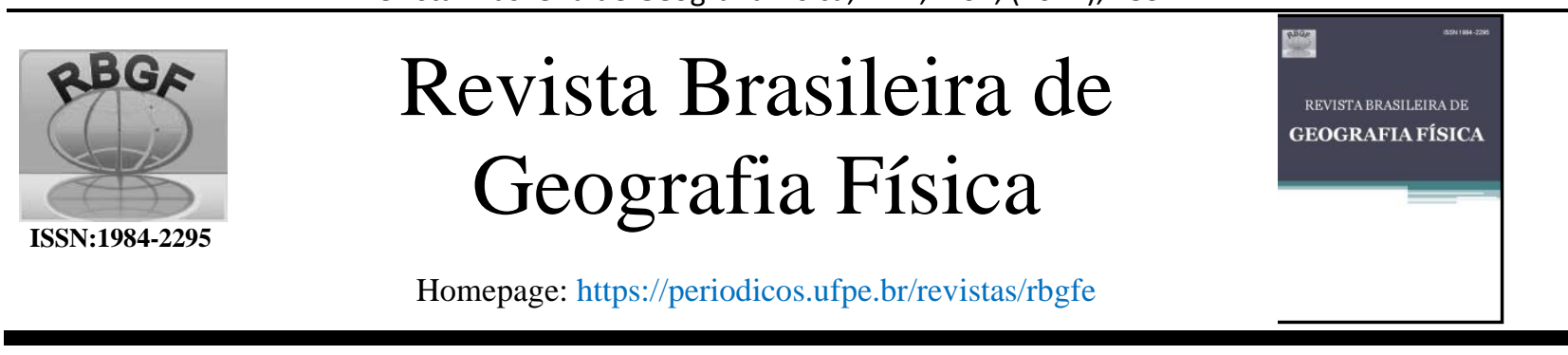

\title{
Urban Environment and the Air Temperature Trend: The Case of the Metropolis of Brazilian Amazon
}

\begin{abstract}
Thaiane Soeiro da Silva Dias ${ }^{1}$, Everaldo Barreiros de Souza ${ }^{2}$, Vânia dos Santos Franco ${ }^{1}$, Álvaro José de Almeida Pinto $^{1}$, Marcelo Cordeiro Thales ${ }^{1}$, Ronaldo Rosales Mendoza ${ }^{1}$, Calil Torres Amaral ${ }^{3}$, Juliana Belmiro Gonçalves ${ }^{3}$, Ilale Ferreira Lima ${ }^{3}$, Greicy Kelly Pfeiff ${ }^{3}$, Júlio Pereira Ribeiro Junior ${ }^{3}$, Marcus Vinicius Silva Da Silva ${ }^{3}$
\end{abstract}

\begin{abstract}
${ }^{1}$ PhD. students, Environmental Science Graduate Program (PPGCA), Federal University of Pará (UFPA), Campus: Basic, Augusto Corrêa, 01, 66075-110, Belém, Pará, Brazil, thaiane.dias24@gmail.com, https://orcid.org/0000-0003-4002-1183 (corresponding author); vsanfranco@yahoo.com.br, https://orcid.org/0000-0002-1970-7634; alvarojalmeidapinto@yahoo.com.br, https://orcid.org/0000-0002-74400053;marcelo.thales@gmail.com, https://orcid.org/0000-0003-3944-6846; ambientalge@gmail.com, http://orcid.org/0000-0002-1139-5082 ; Professor (Associate), Department of Meteorology (FAMET), PPGCA, UFPA, IG, Belém, Pará, Brazil, everaldo@ufpa.br, https://orcid.org/0000-0001-6045-0984; 3 MSc. students, PPGCA, UFPA, IG, Belém, Pará, Brazil, calil.torres@ hotmail.com, https://orcid.org/0000-0002-8910-4353; julianabelmiro18@gmail.com, https://orcid.org/0000-0001-5410-4057; hilalebrades@ hotmail.com, https://orcid.org/0000-0001-5342-2950; greicypfeiff@gmail.com, https://orcid.org/0000-0002-4713-0617; juliopereira1942@hotmail.com, https://orcid.org/0000-0002-8459-7910; silva.v.marcus@gmail.com, https://orcid.org/0000-0002-7959-3798.
\end{abstract}

Artigo recebido em 31/07/2020 e aceito em 01/02/2021.

\section{A B S T R A C T}

Temperature is the focus of many studies around the world due to several factors, such as population growth and land use and coverage changes, as these elements contribute to the increase/decrease of air temperature on the surface of a region. This study aimed to analyze the temperature trend in the metropolises of the Brazilian Amazon (Belém and Manaus), from 1978 to 2018, for the dry and rainy regimes, taking into account population growth and the change in land use and coverage of referred cities. For this purpose, monthly data of maximum, compensated and minimum temperature in a radius of $25 \mathrm{~km}$ from the coordinates of the meteorological stations of each city were used, extracted from the National Institute of Meteorology, usage data and coverage of the Annual Soil Coverage and Use Mapping Project in Brazil and population data of the Brazilian Institute of Geography and Statistics. The results showed a positive trend in the temperature of these regions studied, due to the increase in urban infrastructure and population growth, as well as a decrease in forest formation in the metropolises of the Brazilian Amazon. Key words: Land use and land cover, Population growth, Temperature.

\section{Ambiente Urbano e a Tendência da Temperatura do Ar: O Caso das Metrópoles da Amazônia Brasileira}

\section{R E S U M O}

A temperatura é foco de muitos estudos em todo o mundo devido a vários fatores, como por exemplo, crescimento da população e mudanças de uso e cobertura do solo, pois tais elementos contribuem para o aumento e/ou diminuição da temperatura do ar em superfície de uma região. Neste estudo buscou-se analisar a tendência da temperatura nas metrópoles da Amazônia brasileira (Belém e Manaus), no período de 1978 a 2018, para os regimes seco e chuvoso, levando em consideração o crescimento populacional e a mudança de uso e cobertura do solo das referidas cidades. Para tal, utilizaram-se dados mensais de temperatura máxima, compensada e mínima em um raio de $25 \mathrm{~km}$ a partir das coordenadas das estações meteorológicas de cada cidade, extraídos do Instituto Nacional de Meteorologia, dados de uso e cobertura do Projeto de Mapeamento Anual da Cobertura e Uso do Solo no Brasil e dados populacionais do Instituto Brasileiro de Geografia e Estatística. Os resultados mostraram uma tendência positiva na temperatura das referidas regiões estudadas devido ao aumento da infraestrutura urbana e crescimento populacional, bem como uma diminuição da formação florestal nas metrópoles da Amazônia brasileira. Palavras-chave: Uso e cobertura do solo, Crescimento populacional, Temperatura

\section{Introduction}

Evidence of temperature changes can be the result of different transformation driving forces, from global climate events to regional changes in land use and land cover. Cities are recognized globally as the largest emitters of $\mathrm{CO} 2$ and the largest consumers of energy production (Akbari et al., 2015). At the local scale, the urban environment also concentrates multiple factors that, in synergy control the air temperature, but the degree of paving and verticalization of cities on 
Revista Brasileira de Geografia Física, v.14, n.01, (2021), 159-171.

air temperature are decisive (Alves, 2017; Teixeira and Amorim, 2018).

As a result of the large and rising fraction of the world population living in cities and the disproportionate share of resources used by these urban residents, cities and their inhabitants are the main drivers of global environmental changes (Grimmond, 2007). At the same time, cities are in different proportions and configurations, highly vulnerable to the local effects of rising temperatures, such as the phenomenon of urban heat islands (UHI) (Santamouris et al., 2015). This is the most significant urban weather event and generates thermal discomfort for the local population (Ward et al, 2016; Porangaba; Teixeira and Amorim, 2017). The effects of UHIs in some locations are equal to or greater than the effects of global climate change (Mccarthy, Best and Betts, 2010).

In the Brazilian Amazon, the urban network has expanded diffusely and rapidly since the 1960s, when the opening of large highways in the border areas stimulated a demographic explosion (Trindade Júnior, 2015). This intensive urbanization process, associated with the current forms of territorial ordering, results in urban environments marked by the intrinsic relationship between city and forest, so that the Amazonian cities do not fit into the separate categories of urban or rural. However, despite the close relationship between these spaces, urbanization in the Amazon is still characterized by the intensive economic exploitation of the forest or by the city's indifference to the ecological and cultural potential of these local ecosystems, or even by the recognition of them only as a source of resources for economic exploitation (Trindade Júnior, 2015).

As a result of this condition, on the regional scale, the increasing replacement of forests by pastures has caused an increase in temperature, reduced evapotranspiration, and reduced precipitation (Marengo et al., 2018). The increase in biomass burning, even due to the occurrence of extreme drought events, such as in 2015, is capable of directly impacting the air quality of cities, such as Manaus (Ribeiro et al., 2020). When considering only the local scale, it is clear that the reduction of vegetation cover has intensified the increase in surface temperature in the metropolises (Moreira and Vitorino, 2017; De Barros Lemos et al., 2019) and, associated with the increase in the vehicle fleet, has caused an increase in greenhouse gas emissions (GGE) (Assumpção et al., 2019).

Thus, in the Brazilian Amazon, urban climatology faces the challenge of addressing natural climate variability (NCV), global environmental changes at a fast pace, advancing land cover changes at the regional level and the consequences of an intense and growing urbanization process. In addition, the municipality has played a prominent role as an agent of climate governance, given a polycentric perspective reinforced in the Paris Agreement in 2015 (Wit and Freitas, 2019). Especially in Brazil, municipalities are constitutionally responsible for legislating on environmental policies, in addition to regulating agricultural expansion and urban development. However, it has been registered a low level of institutional capacity; besides, there is no evidence that the municipalities of the cities most threatened by environmental changes are taking proactive measures to reduce their vulnerability (Malhado et al., 2017). That said, it is essential that the climate science in the Amazon develops studies on the consequences of urbanization on climatic conditions. This is the first step towards the incorporation of adaptive measures to the environmental vulnerability of Amazonian cities, and an indispensable step for the consolidation of municipalities as agents of climate governance. The present study aimed to analyze the trend of air temperature between the years 1978 and 2018 in the cities of Belém and Manaus, relating them to changes in land cover and population demographics.

\section{Materials and Methods}

Study area

This study has, as study area, the cities of Belém and Manaus, located respectively in the Eastern Amazon and in the Western Amazon, as shown in Figure 1. Both cities are in the northern region of Brazil and play the roles of metropolises in the region.

\section{Belém}

Capital of the state of Pará, located in the eastern portion of the Amazon, the city of Belém was founded in 1616 and has since gone through an urban expansion process. Currently, with an estimated population of $1.492,745$ inhabitants, it is the second largest city in the region, behind Manaus, in Amazonas. The municipality has a GDP per capita of $\mathrm{R} \$ 20.350$, and a Municipal

160

Dias, T. S.; Souza, E. B.; Franco, V. S.; Pinto, A. J. A.; Thales, M. C.; Mendoza, R. R.; Amaral, C. T.; Gonçalves, J. B.; Lima, I. F.; Pfeiff, G. K.; Junior, J.P.R.; Silva, M. V.S. 
Human Development Index (MHDI) of 0.746, considered average (IBGE, 2019).

The municipal territorial area is defined in $1.059,458 \mathrm{~km}^{2}$; however, the intense process of expansion of the urban network builds a landscape marked by the conurbation with border municipalities. Thus, it joins Ananindeua, Marituba, Benevides, Santa Izabel, Santa Bárbara and Castanhal, to form the Metropolitan Region of Belém (RMB), which has approximately 2.5 million inhabitants (IBGE, 2019).

\section{Manaus}

Capital of the state of Amazonas, Manaus is the largest city in the North Region, with an estimated population of $2.182,763$ inhabitants. The municipality was founded in 1669 and had an impulse of population growth and territorial expansion in the 1960s, as a result of the Installation of the Manaus Free Trade Zone, which attracted investments and labor to the city (IBGE, 2010).

Currently, the city of Manaus has a GDP of $\mathrm{R} \$ 33.564,11$ and an MHDI of 0.737, considered average. In addition, the municipality has a territorial area of $11.401,092 \mathrm{~km}^{2}$, about 10 times greater than that of the municipality of Belém.

\section{Analysis of the air temperature trend}

On the basis of monthly data of maximum, minimum and compensated temperature (1978 to 2018) from conventional weather stations (Belém and Manaus), taken from the Meteorological Database for Teaching and Research (BDMEP) of the National Institute of Meteorology (INMET), we observed the peaks of the rainy and dry regimes of each season. In Belém station, it was observed that the peak of the rainy regime comprises the months of January to May and the dry period comprises the months of August to November. In Manaus station, it was noted that the peak of the rainy regime is between the months of February to April and the dry period between the months of July to September. The averages for each regime (rainy and dry) per year were calculated; based on these, the average of the decades of the following intervals were calculated: 1969-1978, 1979-1988, 1989-1998, 1999-2008 and 2009-2018. After that, the temperature difference between the average decades was measured.

In order to analyze the air temperature trend for the period (1961 to 2018) in the rainy and dry regime, the Mann-Kendall test (Mann, 1945; Kendall, 1975) was applied; it is characterized as a non-parametric test used to verify whether a given data series has a statistically significant temporal trend of change. We tried to observe the rejection or not of the null hypothesis ( $\mathrm{HO})$, of the non-existence of a trend in the data series in relation to the Alternative hypothesis (H1) of the existence of a negative or a positive trend in the observed temperatures. The test provides Kendall's tau, in which a positive or a negative sign indicates an upward or a downward trend, respectively. The p-value was calculated to accept or reject the alternative hypothesis (Souza et al., 2017). In the present article, the significance level $\alpha=0.05$ was used, which is equivalent to $95 \%$.

A radius of $25 \mathrm{~km}$ was considered from the coordinates of the stations in each city to define the area of coverage of climatic conditions captured by the station (Horst and Weil, 1994). This delimitation was important to define the coverage area for the collection of land use and coverage data and demographic data in the selected municipalities, which would be correlated with the climatic data. In Manaus, the $25 \mathrm{~km}$ limit corresponded to the extension of the urban network captured by satellite images. However, since the municipality of Belém contains a much smaller territorial area, the stipulated area exceeded the limits of the municipality, therefore it encompassed the municipalities of Ananindeua, Marituba and Benevides.

\section{Land Use and Land Cover Change}

In order to analyze changes in land use and land cover in the study areas, as one of the possible variables correlated to changes in temperature patterns, the database for the Annual Mapping and Land Use in Brazil Project was used. (MAPBIOMAS). In order to extract the land use and land cover maps (in raster format) within a radius of $25 \mathrm{~km}$ from the weather stations, referring to the years 1985, 1991, 2000, 2010 and 2018, the Google Earth Engine virtual platform was used, while the quantification of the areas $\left(\mathrm{km}^{2}\right)$ of the classes Forest Formation and Urban Infrastructure for each year, in their respective study area, was processed in the geoprocessing software.

Population Demography - Belém and Manaus

Demographic data was used as the second variable to understand the temperature variability. Population growth is an extremely important factor for the study, since both cities, Belém and Manaus, are considered poles of attraction in the region, mainly in their respective states. Moreover, it should be noted that, in the case of 
Revista Brasileira de Geografia Física, v.14, n.01, (2021), 159-171.

Belém, in addition to the population data of the capital, the demographic indexes of the municipalities of Ananindeua, Marituba and Benevides, covered by the $25 \mathrm{~km}$ radius, were also counted. Population data (number of inhabitants) were acquired through the demographic censuses of the IBGE for the years 1985, 1991, 2000, 2010 and the population estimate for 2018 .

\section{Results}

Air temperature trend assessment in the cities of Belém and Manaus

In figure 2 , it is possible to analyze the temperature difference per decade of Manaus, in the period extending from 1979 to 2018, divided in two periods of the year: rainy and dry (less rainy). Note that the difference in maximum temperature in the rainy season (Dif-max_rainy) is greater than the difference in maximum temperature in the dry period (Dif-max_dry), only in the first decade (1979-1988). In the second decade of the study (1989-1998), there is a greater difference in the compensated average temperature of the dry period (Dif-com_dry) in relation to other temperatures.

In the following decade (1999-2008), the difference in maximum temperature between the rainy and dry periods (Dif-max_rainy and Difmax_dry), increased considerably, practically 1.0 ${ }^{\circ} \mathrm{C}$.

Finally, in the last decade of the study (2009-2018), it is the difference in minimum temperature that stands out: an increase of practically $1.5^{\circ} \mathrm{C}$ for both the rainy and dry periods. In the last decade, it is also possible to observe the greatest difference in temperature compensated for the rainy period above $1.0^{\circ} \mathrm{C}$.

Figure 3 shows the temperature difference per decade of Belém. According to the analysis, it is possible to verify that, during the study period, the dry periods presented greater temperature differences in relation to the rainy period; also, there was a tendency to increase the average temperature.

In the decade of 1999-2008, there was a sharp decrease in the minimum temperature in relation to the previous decade; it is also clear that, even with this sharp variation in the minimum temperature from one decade to another, the average continues with an increasing trend in the following decades.

The notorious trend of increase in air temperature in the variables in question in the metropolises of the Amazon shown in figures 2 and 3 were confirmed from the Mann Kendall test (Table 1). As results in the Belém station, the following values could be observed: values between 0.5 and 0.7 (Kendall's tau), in the dry and rainy regimes, and p-value below 0.0005 , thus statistically significant values, except for the Tmax of the rainy regime. In the Manaus station, lower values are noted in Kendall's tau (below $0.5)$ when compared to Belém, but the p-value values are below 0.0005, which shows significance in the trend of the variables, except for the Tmax of the dry regime.

\section{Land use and land cover profile}

Table 2 shows the quantification of the classes (Area in km2) of Forest Formation and Urban Infrastructure for the study areas, Manaus and Belém, and then the changes ( $\%$ change) over the analyzed decades. When analyzing the results, it is possible to verify the increase of the Urban Infrastructure in Manaus by almost 29\% in the 1991 decade, the lowest in the subsequent decades. Concerning Belém, one can observe the largest increase in Urban Infrastructure for the decade of 2000 , of almost $26 \%$, with a subsequent decreasing of this increase in the coming years. It is worth mentioning that, in the period from 1985 to 2018, Manaus infrastructure practically doubled, with a 90\% growth, while Belém registered an increase of $57 \%$. 


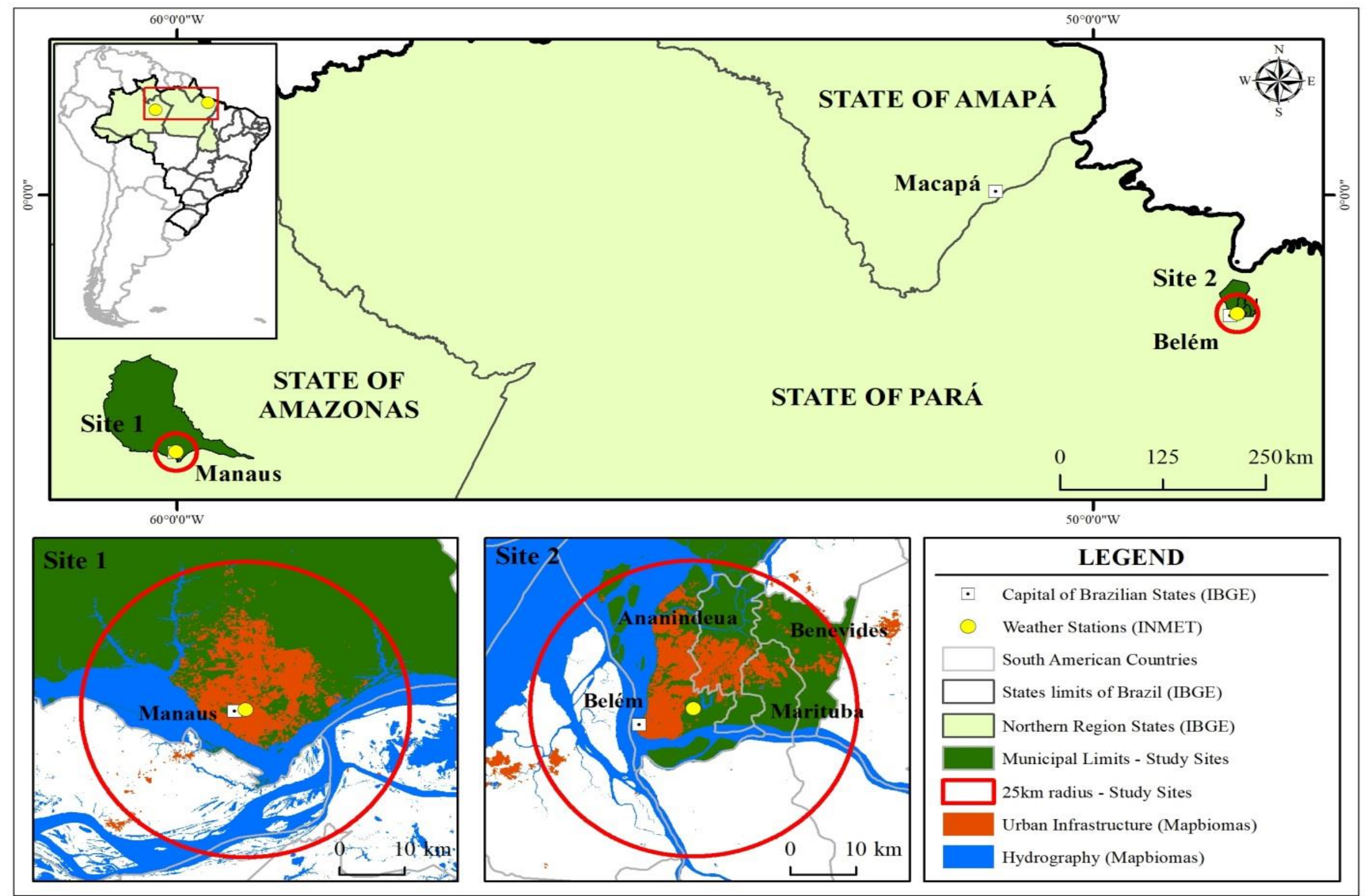

Figure 1. Location map of the study areas. 
Revista Brasileira de Geografia Física, v.14, n.01, (2021), 159-171.

Chart 1 . Information regarding the Meteorological Stations used in the study.

\begin{tabular}{|c|c|c|c|c|}
\hline City & Station & Code & Latitude & Longitude \\
\hline Belém & BELÉM-PA & OMM: 82191 & $-1^{\circ} 26^{\prime} 09^{\prime \prime}$ & $-48^{\circ} 26^{\prime} 14^{\prime \prime}$ \\
\hline Manaus & MANAUS-AM & OMM: 82331 & $-3^{\circ} 06^{\prime} 14^{\prime \prime}$ & $-60^{\circ} 00^{\prime} 56^{\prime \prime}$ \\
\hline
\end{tabular}

Source: INMET

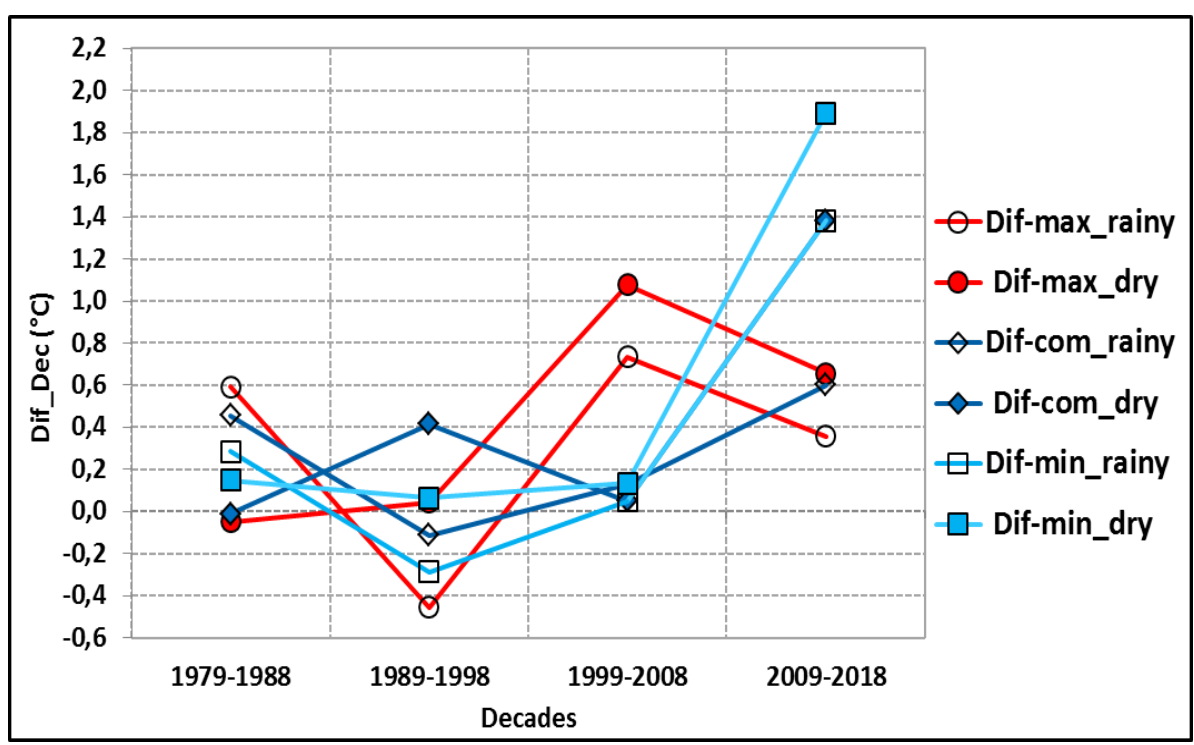

Figure 2. Difference between the data (decades) of the maximum (Tmax), minimum (Tmin) and compensated (Tcom) temperatures of Manaus-AM station for the rainy and dry periods.

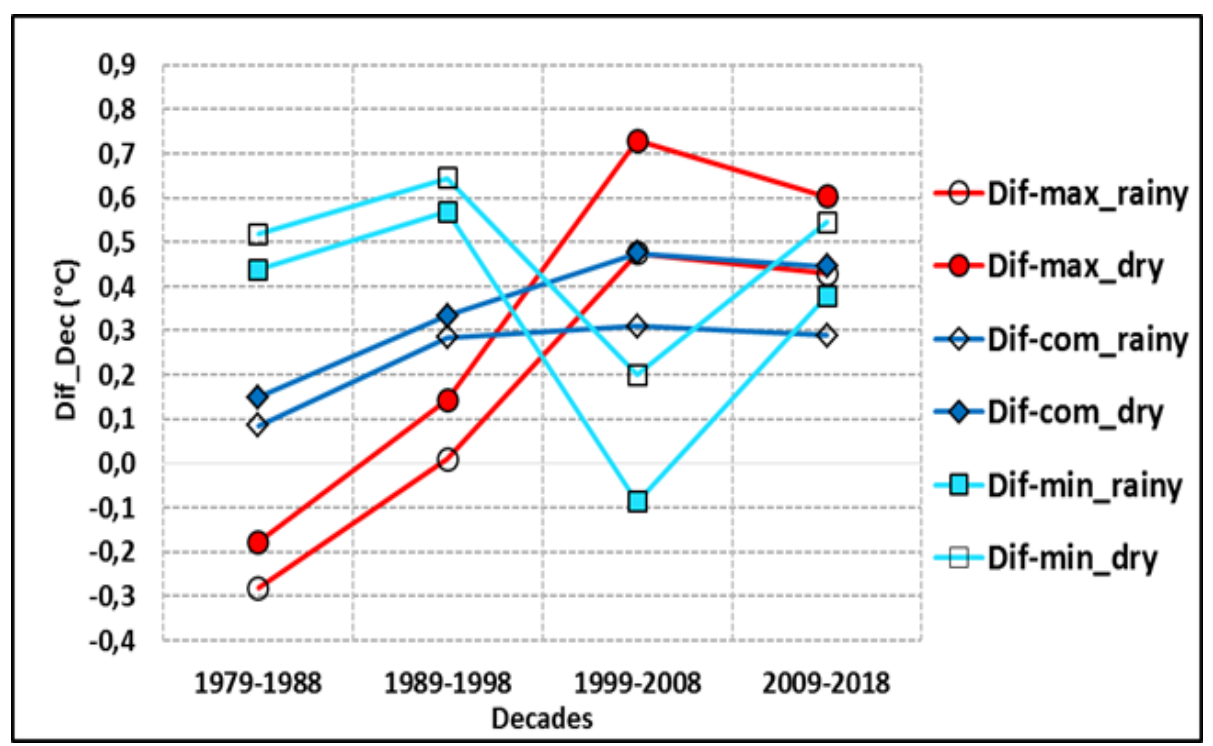

Figure 3. Difference between the data (decades) of the maximum (Tmax), minimum (Tmin) and compensated (Tcom) temperatures of Belém-PA station for the rainy and dry periods. 
Table 1. Mann Kendall's non-parametric test of the variables Maximum (Tmax), compensated (Tcom) and minimum (Tmin) variables of the rainy and dry regimes, for the stations of Belém and Manaus, in the period (1961 to 2018).

\begin{tabular}{|c|c|c|c|c|}
\hline \multirow{2}{*}{$\begin{array}{l}\text { Stations/ } \\
\text { variables }\end{array}$} & \multicolumn{2}{|c|}{ Rainy Regime } & \multicolumn{2}{|c|}{ Dry Regime } \\
\hline & Kendall's tau & $\mathrm{p}$-value & Kendall's tau & p-value \\
\hline \multicolumn{5}{|l|}{ Belém } \\
\hline $\operatorname{Tmax}$ & 0,241 & 0,011 & 0,477 & $<0,0001$ \\
\hline Tcom & 0,492 & $<0,0001$ & 0,665 & $<0,0001$ \\
\hline Tmin & 0,523 & $<0.0001$ & 0,668 & $<0,0001$ \\
\hline \multicolumn{5}{|l|}{ Manaus } \\
\hline $\operatorname{Tmax}$ & 0,382 & $<0,0001$ & 0,289 & 0,001 \\
\hline Tcom & 0,424 & $<0,0001$ & 0,357 & $<0,0001$ \\
\hline Tmin & 0.409 & $<0,0001$ & 0,433 & $<0,0001$ \\
\hline
\end{tabular}

Another way of verifying changes in land use and cover was to quantify the change in the Forest Formation class. In Manaus, there is a reduction of $15 \%$ and $9 \%$, in the periods 1985 1991 and 1991-2000, and in the following periods practically unchanged. While in Belém the reduction of $28 \%$ and $5 \%$ occurred in the periods 1991-2000 and 2000-2010. It is worth mentioning an increase of $14 \%$ between the years 2010 and 2018 in Belém. This increase can indicate a likely constitution of secondary vegetation, since the MapBiomas methodology does not separate the classes. When we analyze the period from 1985 to 2018 , it is possible to see a loss of $21 \%$ and $18 \%$ of Forest Formation in Manaus and Belém, respectively.

In Figure 4, it is possible to spatially analyze the use and cover of the Study Areas. It is observed that the station in Manaus has been located since 1985 in a large region of urban infrastructure. In the following decades, there is an expansion of this class to the northeast of the station and, in the last decade, a small expansion of urbanization (compared to previous decades), mainly to the north of the station.

In Belém, the station is in a region with greater Forest Formation and, in general, the increase in Urban Infrastructure took place just as in Manaus, in the north and northeast.

Analysis of Population Growth

Looking at Table 3, it can be seen that population growth in both regions intensified between the 70s and 80s; despite this, the metropolitan region of Belém continued to have a larger population over the years. However, Manaus remains with the biggest increase until the current years, which attests that both regions have the main nuclei urban areas in the northern region.

In addition, it can be seen in Table 3, within the studied period, a population growth of $582 \%$ for Manaus, which attests that this city had a greater increase over the years, while Belém, in spite of the larger population, had a growth of $242 \%$; thus, the resident population of study passed the 2 million mark in both cities. 


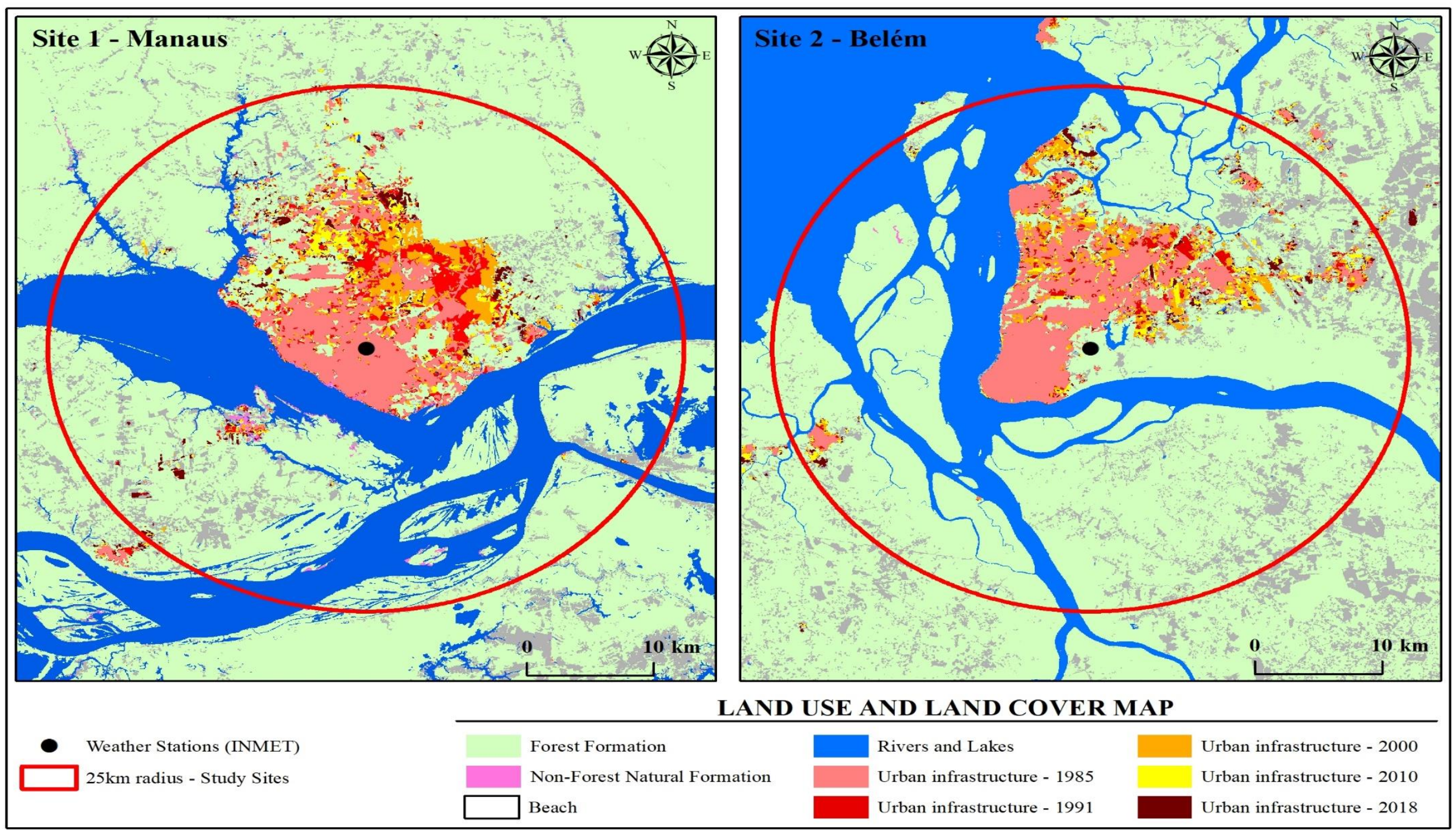

Figure 4 . Use and cover map of the cities of Belém (PA) and Manaus (AM) for the years 1985, 1991, 2000, 2010 e 2018 
Revista Brasileira de Geografia Física, v.14, n.01, (2021), 159-171.

Table 2 . Quantification of areas classified as Forest Formation and Urban Infrastructure for Manaus and Belém for each studied decade.

\begin{tabular}{|c|c|c|c|c|c|c|c|c|}
\hline \multirow[t]{3}{*}{ Year } & \multicolumn{4}{|c|}{ Manaus } & \multicolumn{4}{|c|}{ Belém } \\
\hline & \multicolumn{2}{|c|}{ Forest Formation } & \multicolumn{2}{|c|}{ Urban infrastructure } & \multicolumn{2}{|c|}{ Forest Formation } & \multicolumn{2}{|c|}{ Urban infrastructure } \\
\hline & $\begin{array}{l}\text { Area } \\
\left(\mathrm{km}^{2}\right)\end{array}$ & $\begin{array}{c}\text { Change } \\
(\%)\end{array}$ & Area $\left(\mathrm{km}^{2}\right)$ & Change $(\%)$ & Area $\left(\mathrm{km}^{2}\right)$ & Change $(\%)$ & Area $\left(\mathrm{km}^{2}\right)$ & Change $(\%)$ \\
\hline 1985 & 713,60 & - & 130,06 & - & 507,05 & - & 136,99 & - \\
\hline 1991 & 609,00 & $-14,7 \%$ & 167,47 & $28,8 \%$ & 525,94 & $3,7 \%$ & 144,10 & $5,2 \%$ \\
\hline 2000 & 553,26 & $-9,2 \%$ & 204,19 & $21,9 \%$ & 385,12 & $-26,8 \%$ & 181,28 & $25,8 \%$ \\
\hline 2010 & 554,02 & $0,1 \%$ & 232,35 & $13,8 \%$ & 367,41 & $-4,6 \%$ & 203,73 & $12,4 \%$ \\
\hline 2018 & 561,81 & $1,4 \%$ & 247,01 & $6,3 \%$ & 417,11 & $13,5 \%$ & 215,62 & $5,8 \%$ \\
\hline
\end{tabular}

\section{Discussion}

When talking about temperature, great care should be taken, as there are numerous factors that can influence the behavior of this variable. The ENSO (El-Niño South Oscilation) event can directly and indirectly influence the extremes of rain and temperature in a region,occurring at indefinite time intervals. The phenomena El Niño and La Niña alter the pluviometric and fluviometric regimes, contributing to periods of extreme drought in the Amazon region, affecting the rivers levels, the survival regime of riverside communities, the socioeconomic activities, and the vegetation.

Episodes of El Niño are associated with the weakening of the trade winds, characterized by the warming of the surface water of the Tropical Pacific, where atmospheric pressures decrease in relation to normal (South Oscillation Index - SOI). On the other hand, La Niña is characterized by the cooling of the surface waters of the Tropical Pacific and an increase in the intensity of the trade winds, which reach speeds above average (Britto et al., 2008; Moura et al., 2019).

According to the results, the difference in maximum temperature of the rainy season in Manaus is greater than the difference in maximum temperature of the dry period only in the first decade, which may be associated with El Niño events that occurred within the period: two events of strong intensity (1982-1983 and
1987-1988) and two events of moderate intensity (1979-1980 and 1986-1987) (Barros et al., 2002). In Belém, the behavior of a sudden decrease in the minimum temperature may be associated, in addition to other local factors, to the La Niña event, which occurred three times in this decade, two of moderate intensity (19992000 and 2007-2008) and one of weak intensity (1998-1999). This mechanism has an influence on the region's rainfall, for it changes the radiation balance; hence, the temperature behavior is modified, especially in the rainiest period in Belém, where minimum temperatures tend to be lower (Betts, 2009).

Concerning the positive trend in temperature, the results shown in this study are in agreement with the studies made by De Souza et al. (2015) for the same municipalities, but for the period from 1961 to 2010 , when it was already possible to notice this increase in temperature in the last decades of the referred work. Another study (Salviano et al., 2016), which analyzed the temperature trends for the entire Brazilian territory, found positive values for the average temperature trend for the northern region of Brazil. Another study that observed an increase in air temperature in the North was by Da Silva et al. (2019), who investigated the Amazon and the Northeast of Brazil.

The increase in air temperature is also related to land use and cover. The results 
Revista Brasileira de Geografia Física, v.14, n.01, (2021), 159-171.

presented here show that, in both cities of the study, there was a drastic reduction in vegetation in the period in question.

The increase in temperature is related to several factors, including land use and cover and urban growth. For Eiras-Barca et al. (2020), deforestation has the consequence of altering the hydrological cycle, both on the surface and on the subsurface, which depends directly on the water and energy balance. Ribeiro et al. (2020), in a study related to air quality in the metropolitan region of Manaus combined with the occurrence of extreme events in the Amazon, report that the increase in biomass burning has a direct impact on socioeconomic and environmental factors; the decrease in air quality is the most expressive.

As for the influence on temperature due to land use and cover, Kalnay and Cai (2003) state that it is caused mainly by agriculture and livestock.

Table I . Population growth in the regions of Belém (Metropolitan Region) and Manaus for the decades under study.

\section{Population growth in the studied regions}

\begin{tabular}{|c|c|c|c|c|}
\hline Reference year & Belém & Change (\%) & Manaus & Change (\%) \\
\hline 1970 & 642.514 & - & 314.197 & - \\
\hline 1980 & 1.037 .738 & 61,51 & 642.492 & 104,49 \\
\hline 1991 & 1.401 .304 & 35,03 & 1.010 .544 & 57,29 \\
\hline 2000 & 1.783 .405 & 27,27 & 1.403 .796 & 38,91 \\
\hline 2010 & 2.025 .276 & 13,56 & 1.802 .014 & 28,37 \\
\hline $2018^{*}$ & 2.202 .308 & 8,74 & 2.145 .444 & 19,06 \\
\hline
\end{tabular}

\footnotetext{
*The municipality of Marituba was emancipated in 1994, with the population count estimated from 1996

** 2019 population estimate provided by IBGE

Source: IBGE. Org.: Authors, 2020.
}

Deforestation hinders the exchange of humidity and energy between land and atmosphere, Baker and Spracklen (2019) concluded that the changes (decline) in the leaf area and evapotranspiration index were related to the increase in temperature; therefore, in areas where loss of canopy coverage was greater than $70 \%$, there was an increase of $0.44^{\circ} \mathrm{C}$ in the temperature of the earth's surface.

A study such as those by Souza and Alvalá (2014) in Manaus-AM, Souza et al. (2015) in Belém-PA and Manaus-AM, and Cirino, Vitorino and De Holanda (2019) have shown that the urban expansion process contributes to changes in air temperature, due to the suppression of green areas, greater density of construction and the lack of planning, which impairs the quality of life of people that reside in the region (PBMC, 2016).

The vegetation of the high course of the Igarapé Mindu, for example, has undergone severe changes, mainly due to the urban occupation in the place. Albuquerque and Molinari (2020) emphasize that the accelerated urbanization over the 1980/1990/2000 decades changed the landscape, which is mostly composed of forest fragments.

In Belém, Cabral's study (2014) through satellite images noted the reduction of vegetation cover in protected areas, in a comparison between 1994 and 2009: areas with vegetation conservation had a loss of $7.88 \%$ and areas without vegetation had a $5.15 \%$ increase. Similarly, Moreira and Vitorino (2017) noticed a drop in vegetation cover in relation to the high rates of urbanization, in addition to observing the significant increase in temperature in urbanized areas of Belém.

The results found in this study show that the Amazonian metropolises underwent major changes in urban infrastructure $(90 \%$ in Manaus and $57 \%$ in Belém) in the period from 1985 to 2018 , as well as a large population growth. 
Brazil has been going through a process of intense urbanization, especially since 1960 . The urban population represented $44.7 \%$ of the total population of Brazil, a percentage that increased to $84.4 \%$ in 2010 (IBGE, 2019). Such growth, until the 1980s, occurred mainly in large cities in the country; subsequently, it also reached the intermediate cities of the Brazilian urban network (Ribeiro, 2017).

Although internationally known for the characteristics of its natural ecosystems and for its traditional populations, the Brazilian Amazon has evidently gone through an intense urbanization process (Sathler et al., 2009). According to IBGE census data, the urbanization rate in the North Region, where almost all the Brazilian Amazon is located, jumped from $37.4 \%$, in 1960 , to $73.6 \%$, in 2010 (IBGE, 2019).

Da Trindade Junior (2015) points out that urbanization between the $70 \mathrm{~s}$ and the $90 \mathrm{~s}$ triggered a process of capital metropolization within the Legal Amazon, thus these urban centers, characterized as Belém and Manaus, became attractive in relation to migratory flows, organization of the labor market and politicalideological organization. Further, the author cites (p. 179) that the urbanization process is the "organizing element of a settlement system that defines its structure, its content and its current evolution."

In a study conducted in Manaus, Monteiro et al. (2014) state that urbanization at the expense of removing green areas makes the positive trend in air temperature and relative humidity proportional to the spread of this urban network, as demonstrated in this article. De Barros Lemos et al. (2019) demonstrate that the growth of urbanization in the city of Manaus has caused an increase in the temperature of the capital. The authors also add that there was a predominance of low emissivity of vegetation in the study region, demonstrating that the decrease in the forest cover contributes to an increase in temperature.

A result found by Da Costa et al. (2013) showed that the increase in temperature for locations in the Amazon (Belém-PA, ManausAM, Macapá-AP and Santarém-PA), in the period from 2009 to 2012 , tended to be more influenced by urban characteristics in the drier period, as the rainiest period undergoes changes to large-scale meteorological systems.

Given the above, it is important to understand the dynamics of human interaction with the environment and the consequences caused by changes in land use and occupation in climatic variables, especially in a context of global warming, as local bioclimatic factors can add up to the consequences of global warming in cities. Thus, adaptation processes can be planned for these future scenarios (Souza and Silva, 2017).

\section{Conclusions}

As this study concludes, the positive temperature trend in metropolitan areas in the Brazilian Amazon is mainly due to the increase in urban infrastructure and population growth, as well as a decrease in Forest Formation in these regions. Such a trend may also be influenced by ocean-atmosphere phenomena. Thus, it is suggested to carry out further studies on the subject.

\section{Acknowledgment}

The authors would like to thank PPGCA, UFPA, INMET, to IBGE, the National Council for Scientific and Technological Development (Cnpq), the Coordination of Superior Level Staff Improvement (CAPES) and Amazon Foundation of Support in Studies and Research of the State of Pará (FAPESPA) for carrying out this work.

\section{References}

Albuquerque, N. R., Molinari, D. C., 2020. Caracterização da Cobertura Vegetal no Alto Curso da Bacia do Igarapé do Mindu Manaus (AM). Revista Brasileira de Geografia Física, [S.1.], 13, 1, 406-422.

Alves, E. D. L., 2017. Ilha de calor urbana em cidade de pequeno porte e a influência de variáveis geourbanas. Revista Brasileira de Climatologia, Curitiba, 20.

Akbari, H., Cartalis, C., Kolokotsa, D., Muscio, A., Pisello, A. L., Rossi, F., Santamoures, M., Synnefa, A., Wong, N. H., Zinzi, M., 2016. Local climate change and urban heat island mitigation techniques-the state of the art. Journal of Civil Engineering and Management, 22, 1, 1-16.

Assumpção, M. P.; Tavares, P.A., Coutinho E.C., 2019. Balanço de carbono em cidades da Amazônia: estudo de caso em Belém, Brasil. Urbe. Revista Brasileira de Gestão Urbana, v. 11, 17p.

Baker, J., Spracklen, D., 2019. Climate benefits of intact Amazon forests and the biophysical consequences of 
Revista Brasileira de Geografia Física, v.14, n.01, (2021), 159-171.

disturbance. Frontiers in Forests and Global Change, 2, 47.

Barros, V. R.; Grimm, A. M.; Doyle, M. E., 2002. Relação entre temperatura e circulação no sudeste da América do Sul e sua influência nos eventos El Ninño e La Ninña. Jornal da Sociedade Meteorológica do Japão. Ser. II, 80, 1, 21-32.

Betts, A. K., 2009. Land-surface-atmosphere coupling in observations and models. Journal of Advances in Modeling Earth Systems, 1, 3, 18.

Britto, F. P.; Barletta, R.; Mendonça, M., 2008. Variabilidade espacial e temporal da precipitação pluvial no Rio Grande do Sul: influência do fenômeno El Niño Oscilação Sul. Revista brasileira de climatologia, 3, 37-48.

Cabral, C. L., 2014. Geografia da Área Protegida: uma abordagem sobre os efeitos da expansão urbana na qualidade de vida da APA Metropolitana de Belém-PA (19942009). Papers do NAEA (UFPA), 326, 4.

Cirino, L. Dos S.; Vitorino, M. I.; De Holanda, B. S., 2019. Análise climática da variabilidade natural e antrópica para uma metrópole amazônica. Revista Brasileira de Iniciação Científica, 6, 2, 3-26.

Da Costa, A. C. L.; Silva Júnior, J. D. A.; Cunha, A. C. D.; Feitosa, J. R. P.; Portela, B. T. T.; Da Silva, G. G. C.; Da Costa, R. F., 2013. Índices de conforto térmico e suas variações sazonais em cidades de diferentes dimensões na Região Amazônica. Revista Brasileira de Geografia Física, 6,03, 478487.

Da Silva, P. E., Santos e Silva, C. M., Spyrides, M. H. C., \& Andrade, L. D. M. B., 2019. Precipitation and air temperature extremes in the Amazon and northeast Brazil. International Journal of Climatology, 39, 2, 579-595.

Da Trindade Júnior, S. C., 2015. Grandes projetos, urbanização do território e metropolização na Amazônia. Terra Livre, 1, 26, 177-194.

De Barros Lemos, M., De Lima, A. A., Corrêa, P. B., \& Bezerra, I. F. O., 2019. Surface Temperature and NDVI Behavior Analysis in September in Manaus/AM City. International Journal of Advanced Engineering Research and Science, 6, 11, $467-474$.

De Souza, D. O., Do Nascimento, M. G., Dos Santos Alvalá, R. C., 2015. Influência do crescimento urbano sobre o microclima de Manaus e Belém: um estudo observacional. Revista Brasileira de Geografia Física, 8, 4, 1109-1124.

De Sousa, E. B., Ferreira, D. B. S., Guimarães, J. T. F., Franco, V. Dos S., Azevedo, F. T. M. De, Moraes, B. C. De; De Souza, P. J. De O. P., 2017. Padrões climatológicos e tendências da precipitação nos regimes chuvoso e seco da Amazônia oriental. Revista Brasileira de Climatologia, 21, 8193.

Eiras-Barca, J., Dominguez, F., Yang, Z., Chug, D., Nieto, R., Gimeno, L. and MiguezMacho, G., 2020. Changes in South American hydroclimate under projected Amazonian deforestation. Ann. N.Y. Acad. Sci., 1472, p. 104-122.

Grimmond S.U., 2007. Urbanization and global environmental change: local effects of urban warming. Geographical Journal, 173, $1,83-88$.

Horst, T. W.; Weil, J. C., 1994. How far is far enough?: The fetch requirements for micrometeorological measurement of surface fluxes. Journal of Atmospheric and Oceanic Technology, 11, 4, 1018-1025.

IBGE - Instituto Brasileiro de Geografia e Estatística. IBGE Cidades: Manaus-AM. Disponível em <https://cidades.ibge.gov.br/brasil/am/mana us/panorama>. Acesso em 08 dez. 2019.

IBGE - Instituto Brasileiro de Geografia e Estatística. IBGE Cidades: Belém-PA. Disponível em $<$ https://cidades.ibge.gov.br/brasil/pa/belem /panorama>. Acesso em 08 dez. 2019.

IBGE - Instituto Brasileiro de Geografia e Estatística. População nos Censos Demográficos, segundo os municípios das capitais - 1872/2010. Disponível em: $<$ https://censo2010.ibge.gov.br/sinopse/inde x.php?dados $=6 \& u f=00>$. Acesso em 08 dez. 2019.

Kalnay, E., Cai, M. 2003. Impact of urbanization and land-use change on climate. Nature, 423, 6939, 528.

Kendall, M.G., 1975. Rank Correlation Measures. Charles Griffin, London.

Moura, M. M., dos Santos, A. R., Pezzopane, J. E. M., Alexandre, R. S., da Silva, S. F., Pimentel, S. M., De Andrade, M. S. S., Silva, F. G. R., Branco, E. R. F., Moreira, T. R., Da Silva, R. G., De Carvalho, J. R., 2019. Relation of El Niño and La Niña phenomena to precipitation, 
Revista Brasileira de Geografia Física, v.14, n.01, (2021), 159-171.

evapotranspiration and temperature in the

Amazon basin. Science of The Total Environment, 651, 1639-1651.

Mann, H. B., 1945. Econometrica. The Econometric Society, 13, 3, 245-259.

Malhado, A. C., Costa, M. H., Correia, R. A., Malhado, A. C., de la Fuente, M. F. C., da Costa, A. M., Batinga, J. V., Bragagnolo, C., Ladle, R. J., 2017. Are capacity deficits in local government leaving the Amazon vulnerable to environmental change?. Land Use Policy, 69, 326-330

Marengo, J. A., Souza Jr, C. M., Thonicke, K., Burton, C., Halladay, K., Betts, R. A., Alves, L. M., Soares, W. R., 2018. Changes in climate and land use over the Amazon region: current and future variability and trends. Frontiers in Earth Science, 6, 228.

Mccarthy, M.P., Best, M. J., Betts, R. A., 2010. Mudança climática nas cidades devido ao aquecimento global e aos efeitos urbanos. Cartas de Pesquisa Geofísica, 37, 9.

Monteiro, J. C. R., Aride, P. H. R., Oliveira, A. T. de, Santos, S. M., Pantoja-Lima, J., Heyer, L. F., 2014. Descrição da temperatura e umidade relativa do ar em diferentes localidades no bairro do Parque Dez - Manaus/AM. Biota Amazônia. Macapá, 4, 2, 20-27.

Moreira, F. S. De A.; Vitorino, M. I., 2017. Relação de áreas verdes e temperatura da superfície para cidade de Belém. Paper Naea: 369. Belém.

PBMC, 2016: Mudanças Climáticas e Cidades. Relatório Especial do Painel Brasileiro de Mudanças Climáticas [Ribeiro, S.K., Santos, A.S. (Eds.)]. PBMC, COPPE UFRJ. Rio de Janeiro, Brasil. 98p. ISBN: 978-85-285-0344-9.

Pitman, A.J., Zhao, M., 2000. "The relative Impact of observed change in land cover and carbon dioxide as simulated by a climate model". Geophys. Res. Lett., 27, 1267-1270.

Porangaba, G. F. O., Teixeira, D. C. F., Amorim, M. C. C. T., 2017. Procedimentos metodológicos para análise das Ilhas de Calor em cidades de pequeno e médio porte. Revista Brasileira de Climatologia, Curitiba, 21, 13, 225-247.
Ribeiro, I. O., do Santos, E. O., Batista, C. E., Fernandes, K. S., Ye, J., Medeiros, A. S., E Oliveira, R. R., De Sá, S. S., De Sousa, T. R., Kayano, M. T., Andreoli, R. V., Machado, C. De M. D., Surrat, J. D., Junior, S. D., Martin, S. T., De Souza, R. A. F., 2020. Impact of biomass burning on a metropolitan area in the Amazon during the 2015 El Niño: The enhancement of carbon monoxide and levoglucosan concentrations. Environmental Pollution, 260.

Ribeiro, M. A. C., 2017. O urbano na Amazônia e as consequências ambientais. Boletim Paulista de Geografia, 80, 89-108.

Santamouris, M., 2015. Regulating the damaged thermostat of the cities-Status, impacts and mitigation challenges. Energy and Buildings, 91, 43-56.

Salviano, M. F., Groppo, J. D., Pellegrino, G. Q., 2016. Trends Analysis of Precipitation and Temperature Data in Brazil. Revista Brasileira de Meteorologia, 31, 1, 64-73.

Sathler, D., Monte-Mór, R. L., Carvalho, J. A. M., 2009 As redes para além dos rios: urbanização e desequilíbrios na Amazônia brasileira. Nova economia, 19, 1, 11-39.

Souza, D. O., Alvalá, R. C. S., 2014. Observational evidence of the urban heat island of Manaus City, Brazil. Meteorological Applications, 21, 2, 186193.

Souza, C. A.; Silva, M. H. S., 2017. Análise da distribuição térmica da cidade de Campo Grande, Mato Grosso do Sul. Revista Brasileira de Climatologia, Curitiba, 21, 13.

Teixeira, D. C. F.; Amorim, M. C. D. C. T., 2018.0 estudo da ilha de calor em cidade de pequeno porte: algumas contribuições. Revista Sociedade \& Natureza, Uberlândia, 30, 2, 186-209.

Ward, K., Lauf, S., Kleinschmit, B., Endlicher, W., 2016. Heat waves and urban heat islands in Europe: A review of relevant drivers. Science of the Total Environment, 569, 527-539.

Wit, F.C.A., Freitas, P.M., 2019. Global climate adaptation governance in the Amazon through a polycentricity lens. Revista Brasileira de Política Internacional, 62, 2. 